\title{
Factors Influencing Dividend Payout Ratio: Evidence from KSE 100 Index Pakistan
}

\author{
MANZOOR ALI \\ Student, Abdul Wali Khan Universit, Mardan \\ MUHAMMAD ISRAR \\ Student, Abdul Wali Khan University, Mardan \\ ADNAN KHAN \\ Student, Abdul Wali Khan University, Mardan \\ DR. JEHANGIR \\ Assistant Professor, Abdul Wali Khan University Mardan \\ Jehangir@awkum.edu.pk
}

\begin{abstract}
This research is an effort to make known the insight dynamics for determination of Dividend Payout regarding Non-Financial Firms listed in the KSE100 Index. In light of prior literature, key explanatory variables were identified to reveal their relationship and effect on determination of dividend payout. These variables are Changes in stock prices, Previous year dividend, Change in current year earnings and Change in sales. Through observation, 42 such companies were identified from the listed non-financial firms in the Karachi Stock Exchange that have been paying out dividend consistently for the past period from 2006 to 2014. Ordinary Least Square (OLS) was identified as the most appropriate tool for econometric analysis of the data. The descriptive statistics revealed the data to be normal. OLS result shows insignificant negative relationship of changes in sales and changes in stock prices with dividend payout ratio. Change in current year earning has significant negative relationship with dividend payout ratio while previous year dividend has significant relationship with dividend payout ratio. Since Dividend is an unsolved puzzle, thus there is implication for future research. Many other variables that have significance in context of Pakistan and past literature can be added to this regression to increase the explanatory power of the model.
\end{abstract}

Keywords: Dividend policy; Previous year dividend; Change in sales; Change in current year earnings; Change in stock price

\section{Introduction}

Formulation of dividend policy is an important task of the management of a company. The decision of corporate dividend policy relates with the question that which 
proportion of the firm's earning should be distributed among the shareholders as dividend and which proportion should be kept in the business to reinvest it in the profitable projects. Management considers which policy is better to maximize shareholder's wealth and also concentrates that how much is needed for reinvestment because they also take into account the impact of dividend policy decision on company stock prices (Hashemijoo, Ardekani \&Younesi, 2012). The management basic goal is to maximize the wealth of shareholders. Shareholders invest their capital with the expectation that they will get their return and principal amount back in the form of dividend or capital gain (Shlifer \& Vishnay 1996). Management pay dividend to share holder from the profit and keep remaining profit under the head of retained earnings. If firm forecasts good investment opportunity in future and wants to finance with the existing shareholder's capital then its retention ratio is higher than the dividend payout ratio. Baker and Powel (1999) explained that industry specific factors and future earning level are the major factor which affects dividend policy.

Investors want to invest in to such a company which is stable. If a company issue high dividend in one year and then, in next year, it pays low dividend which is not a good signal for the shareholder. This may affect the stock prices negatively in the stock market. In the corporate finance literature, firm's dividend policy has a prominent place and still studies are conducted in developed and emerging countries but no one can provide an acceptable explanation for the determinants and behavior of dividend (Black, 1976; Allen \& Michaely, 2003; Brealey \& Myers, 2005). Dividend Policy is included by the Brealey and Myers (2005) in the one of the top ten unsolved issue of corporate finance. Smoothing the firm's dividends as well as earnings and growth is one of the famous explanations of the dividend behavior. In United States, firms smoothly adjust their dividend for maintaining their target long run payout ratio (Linter, 1956). After Linter 1956, several studies are conducted which submit that dividend behavior fluctuate from country to country due to various institutions and capital market differences.

Capital gain and dividend both are increase the purchasing power shareholders. Company management decided dividend and also their efforts and team work add value to the firm. When managers decide to pay low dividend in case of high profit then debt holders will react because it decrease assets against the claim of debt holders and in case of high profit and low dividend payout then shareholders will react. Fama and Jensen, (1983a, 1983b), Barnea, Huagen \& Senbet, (1981) support that claim priority influence dividend policy. Now the question arises "what happens when the firm announces its dividend policy to overcome the investor reaction if it pays low dividend in case of high current year earning?". How the stock price changes affect the firm's dividend policy? This is the main objectives of this study is to investigate the firm's decision about its dividend payout ratio using changes in stock prices, previous year dividend, changes in sales and changes in current year earnings. 


\section{Literature Review}

As regards the empirical literature the roots of the literature on determinants of dividend policy is related to Linter (1956) seminal work. After Linter (1956) Fama and Babiak (1968) extend the model. Higgins (1972) claims that a firm's need for funds to invest growth opportunity has adverse association with payout ratio. Higgins (1981) directs a through link between growth and financing needs: Speedily growing firms have outside financing needs because working capital needs usually exceed the incremental cash flows from new sales. Rozeff (1982), Lloyd et al. (1985), and Collins et al. (1996) claimed that historical sales have significant negative relationship with dividend payments and dividend growth. Partington (1983) stated that firms practice of target payout ratios, firms desire for disbursing dividends, and degree to which dividends are determined are self-determining of investment policy. Baker et al. (1985) mentioned the future earning level of the firms as a major determinant of dividend payout. Profit have identified as the primary indicator of dividend payment capacity of the firms. In a similar manner, Pruitt and Gitman (1991) documented that profits of current and past year of the firms are the important influencing factors of dividend payments. They further stated that variability of earning from year to year (risk) also effect dividend payments. A firm with relatively stable earning is able to predict its future earnings and the payout ratio of such firms are higher than its retention ratio. While firms with fluctuating earning pay low dividend. Adaoglu (2000) observed that firms follow unstable cash dividend policy and that earnings of the firms are important factor determining dividend policy in case of Istanbul Stock Exchange listed firms.For a sample of firms listed at Karachi Stock Exchange, Mehar (2003) investigated the behavior of dividend changing firms' and found that 23 percent incremental profits are paid as dividend and the remaining profit are used for investing in the projects. The study explained that concentrated ownership also has effect on dividend policy and firm start dividend after a certain level of growth.

De Angelo et al. (2004) observed significant relationship between dividend payment decisions and the ratio of earned equity to total equity controlling for size of the firm, cash balance, leverage, dividend history, growth and profitability. Eriotis (2005) documented that firms pay dividend each year according to their target payout ratio which is determined by distributed earnings and firm size in Greek. Reddy (2006) investigated Indian firms and found that firms large in size, with high profits and growth pay dividend and supports the theory of corporate tax in Indian background. Amidu and Abor (2006) found that the dividend policy of the firms listed on Gahan Stock Exchange is affected by cash flow, profitability and growth and investment opportunity. Kumar (2006) found that investment opportunities, earning trends, dividend history and ownership structure are most important factors influencing dividend payout ratio in India. Kumar further found negative relationship between investment opportunity and dividend payout ratio while negative in case of earning trends and debt equity ratio and institutional ownership and dividend payout ratio. 
Nacuer et al. (2006) found that firms with high profits and stable earnings can maintain larger cash flows, which enables them to pay higher dividends. Further, they argue that to attract investor, fast growing firms pay more dividend. Megginson and Eije (2006) observe a decline of dividend paying tendency while studying fifteen European firms during the period from 1989 to 2003 . Dividend payout does not increase with an increase in retained earnings to total equity while company age does. In case of Canadian firms, Baker et al. (2007) documented that dividend paying companies have greater cash flows, are more profitable, larger in size and have growth opportunities. Ahmed and Javid (2008) examined 320 nonfinancial firms listed at Karachi Stock Exchange during 2001 to 2006. They found that past year dividend and earnings per share influence dividend policy of nonfinancial firms. However, dividend policy is more sensitive to current earnings than prior dividends further, firm earnings stability enable them to manage larger free cash flow and pay high dividend. Ahmed and Attiya (2009) reported that dividend payout ratio of Pakistani firms rely on current year earnings and past dividend. Furthermore, they observed that firm with stable positive net earnings pay high dividend while market liquidity and ownership concentration has positive relationship with dividend payouts. Though, the relationship between growth opportunity and payout is insignificant and reported negative relationship of size and dividend payout for which they argued that large companies prefer to invest in assets rather than paying dividend.

Nishat and Waliulah (2010) result shows that liquidity, profitability and leverage are most influential factors effecting dividend policy of Pakistani firms. Firms of high equity pay less dividend and companies of large size are likely to pay higher dividend. Their result also suggest that government ownership increase the dividend payout, companies having growth opportunity expected not to increase dividend. They observed that financial reforms have positive effect on dividend and argued that secondary market development has important implications for dividend decision. Asif, Rasool and Kamal (2010) investigated the dividend policy with financial leverage of the firms listed on Karachi Stock Exchange. They examined 403 companies for the period of 2002 to 2008. They tested firm's debt ratio, prior year dividend yield as independent variable, earnings changes as dummy variable while dividend policy as dependent variable by using Linter (1956) extended model. Descriptive statistics and correlation matrix is used to find out the primary relationship among the variables. To find out the significance and magnitude, regression analysis on panel data is used through fixed and random effect model. They concluded that leverage has negative impact on dividend policy while high levered firms pay low dividend. They further revealed that changes in earning effect dividend policy nonetheless the result was insignificant however they found positive impact of dividend yield on dividend policy in case of Pakistani firms. Asif et al. (2011) observed that corporate debt and dividend payout has significant negative relationship while change in earning has no effect on dividend payment in case of Pakistani listed firms. Imran (2011) studied 63 companies listed at Karachi stock exchange for the period of 1996 to 2008. Imran recommended that previous dividend per share, size of firm, cash flow, sales 
growth, profitability, earning per share play prominent role in determination of dividend policy in the engineering sector of Pakistan. Rafique (2012) examine 53 nonfinancial firm listed at Karachi stock exchange for the period 2005 to 2010. Study result revealed that firm size and corporate tax have significant relationship with dividend payout ratio while financial leverage, profitability, growth, and earnings are irrelevant with dividend policy in case of Pakistani firms. Mehta (2012) examined factors influencing dividend policy of all the firms listed on Abu Dhabi Stock exchange for the period of five years ranging from 2005 to 2009 in the sector of health care, industrial, telecommunications, construction, energy, real estate excluding banking sectors. The study inspected leverage, size, liquidity, risk, and profitability as the determinant of dividend policy. The result show that size and profitability are the most important variable influencing the dividend policy decision of the UAE firms.

\section{Methodology}

The purpose of this dissertation is to investigate the impact of stock prices fluctuations on payout policy of listed Karachi Stock Exchange (KSE) firms during the period 2006-2014. The total population of the study comprise 42 firms from nonfinancial firms. The current study extracted a sample of 42 firms' on the basis of certain criteria's: (1) a firm has to be listed at KSE at the entire duration of the study, it should not to be delisted during the study period; (2) further a firm is included in the sample if it has data availability on all variables; and (3) finally firm's which pay dividend during the mentioned period are to be included in the sample. These restrictions on sample selection finally produce a final sample of 42 firms. The hypothesis as previously mentioned are to be tested using Descriptive statistics, correlation and Ordinary Least Square (OLS). The study will use and analyze secondary data which will be collected from annual reports of these companies published by the Karachi Stock Exchange and State Bank of Pakistan for the time period of 2006 to 2014 .

\subsection{The Model of the Study}

As previously indicated the study will run the following regression model to test the research hypothesis. Stata 12 is to be used to estimate the results. The dependent variable of the study is dividend payout ratio while explanatory variables incorporated on the right side of the regression are lag dividend payout, stock price changes, current year earnings, change in sales. The current study incorporated Ordinary Least Square (OLS) to test the effect of independent variable which are changes in stock prices, previous year dividend, change in current year earnings and changes in sales on dependent variable dividend payout ratio. The general form of model is shown below:

$Y_{\mathrm{it}}=\alpha+\beta_{1} X_{1 \mathrm{it}}+\beta_{2} \mathrm{X}_{2 \mathrm{it}}+\beta_{3} \mathrm{X}_{3 \mathrm{it}} \ldots \ldots \ldots . . \beta_{\mathrm{n}} \mathrm{X}_{\mathrm{nit}}+\varepsilon$

Where,

$\mathrm{Y}$ is the dependent variable of the study which is dividend payout; $\beta 1 \ldots . . . \mathrm{Bn}$ are the coefficients whereas X1it.....Xnit represent the explanatory variables for firm i (i.e. $i=$ $1 \ldots \ldots 42$ ) for period $t$ (i.e., $t=1 \ldots \ldots .9$ ); $\alpha$ is the constant of the equation; and $\varepsilon$ is the error term. The final form of model is: 
$P O R=\alpha+\beta_{1} \Delta S P+\beta_{2} P Y D+\beta_{3} \Delta C Y E+\beta_{4} \Delta S L+e$

Model estimates the impact of change in stock prices on dividend payout ratio while controlling for previous year dividend, change in current year earnings and change in Sales.

\section{Data Analysis and Discussion}

This explains analyses and results of the thesis. The chapter analyzes 42 firms listed on Karachi Stock Exchange to analyze the effect of change in stock prices on dividend policy by taking changes in sales, changes in earnings and previous year dividend as control variables.

\subsection{Descriptive statistics}

Table 4.1 presents the descriptive statistics for the variables included in the model to examine the dividend policy of firms listed on the Karachi stock exchange of Pakistan from 2006 to 2014 .

Table 4.1: Descriptive Statistics

\begin{tabular}{|cccccc|}
\hline Variable & Obs. & Mean & Std. Dev. & Min & Max \\
\hline POR & 378 & 44.31959 & 51.49048 & -51.03294 & 823.8038 \\
$\Delta$ SP & 378 & 22.17655 & 58.83677 & -79.88981 & 422.9322 \\
PYD & 378 & 44.76654 & 51.59068 & -51.03294 & 823.8038 \\
$\Delta$ CYE & 378 & -19.09528 & 344.5117 & -6427.937 & 358.5726 \\
$\Delta$ SL & 378 & 14.29114 & 16.24939 & -56.80441 & 100 \\
\hline
\end{tabular}

The mean value of Payout ratio (POR) is 44.32 with a value of 51.50 standard deviation, the mean of the dividend payout ratio (POR) indicates that the firm's average payout ratio is $44.32 \%$ where minimum payout is $-51.03 \%$ and maximum payout is $823.80 \%$ The standard deviation of POR indicates that POR is not volatile during the session. The independent variable, Change in Stock Prices $(\Delta \mathrm{SP})$ has a mean value of 22.18 which shows that average change in stock prices is $22.18 \%$ and standard deviation value of 58.84 shows volatility in Change in Stock Prices $(\Delta \mathrm{SP})$. Similarly the average value of previous year dividend (PYD) is $44.76 \%$, with standard deviation of $51.59 \%$ which shows low volatility. The average change in Current year earning ( $\triangle \mathrm{CYE})$ observed is $19.09 \%$ with standard deviation of 344.51. Moreover, Standard deviation of change in Current year earning ( $\triangle \mathrm{CYE})$ show high dispersion. The average change in sales $(\Delta \mathrm{Sl})$ is 14.29. Standard deviation of change in sales shows that there is low volatility. The reason of the volatility of variable is the minimum and maximum values distance from the mean because our sample size is consist on different firms from different sectors of industries of Karachi Stock Exchange Pakistan. Following Chart shows variability of Data around the mean value. 


\subsection{Correlation Matrix}

Table 4.2 presents the correlation matrix for the variables included in the model to examine the dividend policy of firms listed on the Karachi stock exchange of Pakistan from 2006 to 2014

Table 4.2: Correlation Matrix

\begin{tabular}{|c|c|c|c|c|c|}
\hline & POR & $\Delta \mathbf{S P}$ & PYD & $\Delta \mathbf{C Y R}$ & $\Delta \mathbf{S L}$ \\
\hline POR & 1.0000 & & & & \\
\hline$\Delta \mathbf{S P}$ & $\begin{array}{l}-0.1200 \\
(0.0196)\end{array}$ & 1.0000 & & & \\
\hline PYD & $\begin{array}{c}0.2157 \\
(0.0000)\end{array}$ & $\begin{array}{l}-0.0049 \\
(0.9236)\end{array}$ & 1.0000 & & \\
\hline$\Delta$ CYR & $\begin{array}{l}-0.7786 \\
(0.0000)\end{array}$ & $\begin{array}{c}0.1252 \\
(0.0148)\end{array}$ & $\begin{array}{c}0.0494 \\
(0.3380)\end{array}$ & 1.0000 & \\
\hline$\Delta \mathbf{S L}$ & $\begin{array}{l}-0.0613 \\
(0.2343)\end{array}$ & $\begin{array}{c}0.1100 \\
(0.0325)\end{array}$ & $\begin{array}{c}0.0465 \\
(0.3671)\end{array}$ & $\begin{array}{c}0.0610 \\
(0.2371)\end{array}$ & 1.0000 \\
\hline
\end{tabular}

Note: The p-values are shown in brackets.

The payout ratio and the change in stock prices has -0.12 correlation which is significant at 0.05 level which shows that change in stock prices has significant negative correlation with dividend payout ratio. A positive change in stock price (capital gain) effect negatively dividend payout ratio of Pakistani firms listed at Karachi stock exchange. Previous year dividend (PYD) has significant positive relationship with dividend payout ratio. Similarly, Change in current year earnings $(\Delta C Y R)$ has significant negative co relationship with dividend payout ratio. Furthermore, change in sales $(\Delta \mathrm{SL})$ also negatively affect dividend payout ratio but this relationship is insignificant of the selected firms.

\subsection{Ordinary Least Square}

The total number of observation of the study are 378. The F-value of 190.94 is significant at $5 \%$ level which mean that our model is significant. The R-square value is $0.67 \%$ which indicate that all four variable explains $67 \%$ of the variation in defendant variable POR. The remaining $33 \%$ is due to some other factors. Thus our study variables explain greater variation in POR. 
Table 4.3: Ordinary Least Square

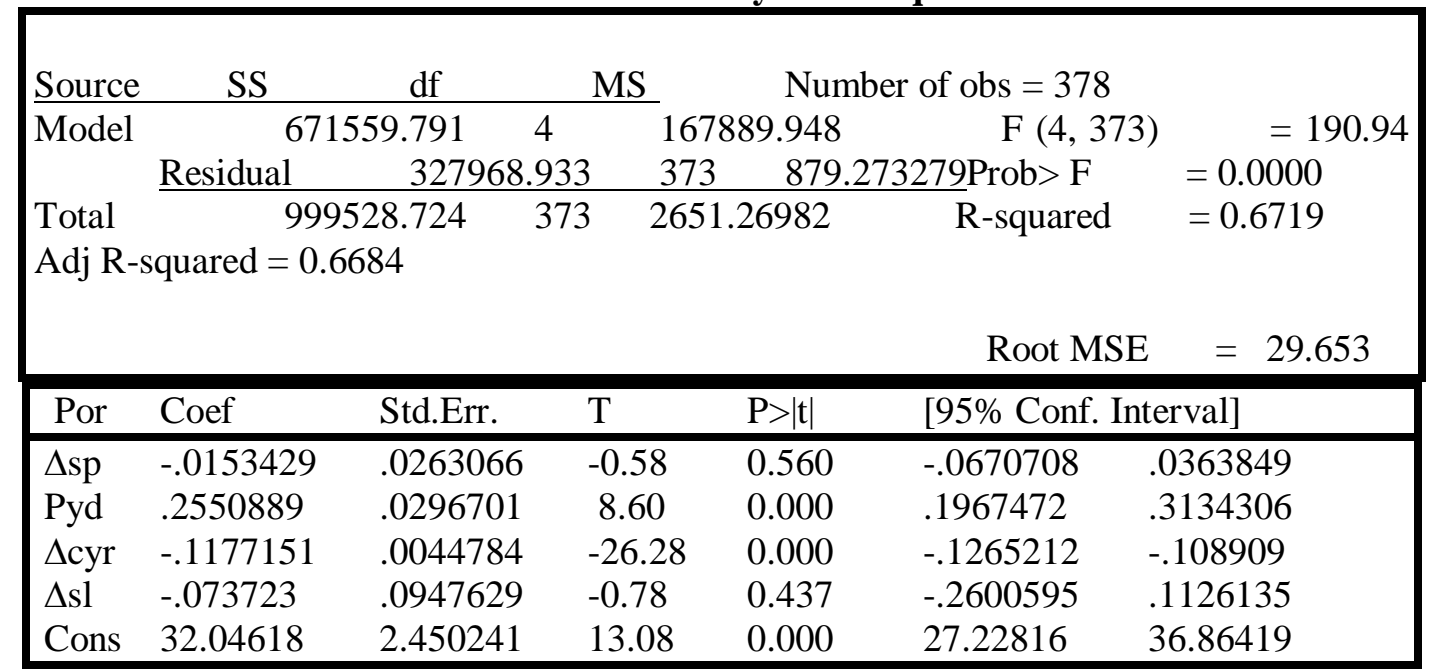

The correlation between change in stock price variable and payout ratio is negative which show that an increase in stock prices decrease payout ratio, however, the relation is not statistically significant at the 5\% level. Therefore, H1 cannot be accepted. On the other hand the association between lag dividend which is previous year dividend is positive and there is enough evidence in support of the relation as shown by p-value of 0.000 . This result imply that firm which have previous dividend paying history or dividend stability will transform it into the future and will pay dividend. Thus $\mathrm{H} 2$ is accepted. Furthermore, the variable change in current year earnings in contrast negatively affect dividend payout ratio KSE firms and the result is significant at the 5\% level as shown by $\mathrm{p}$ and t-value. The result imply that an increase in current year earnings decline POR which is against Linter (1956) which argued that current year earnings positively affect dividend payout ratio. Firms with earning growth will have higher investment opportunities, therefore, they pay less dividend. Additionally, the variable changes in sales has negatively relationship dividend payout ratio but this relation is insignificant at $5 \%$ level. Thus due to lack of statically evidence the hypotheses 4 is rejected.

\section{Conclusion}

The present study investigates the factors determine the dividend payout ratio of Pakistani nonfinancial firms listed on Karachi Stock Exchange by using the panel technique like OLS of forty-two firms during the period from 2006 to 2014. The results show that changes in stock prices is negatively affect dividend payout ratio of the selected firms but this relationship is insignificant. In the light of our result we can conclude that capital gain/loss has no effect on dividend payout ratio of Pakistani listed firms. Previous year dividend has significant positive relationship with dividend payout ratio. This positive relationship mean that firms with dividend paying history transform it to future. Ahmed and Javid (2008) also find out that past year dividend influence 
dividend payout ratio in case of Pakistani firms. Ahmed and Attiya (2009) results suggest that Pakistani firms relay on past year dividend while deciding dividend payout. Pandey (2001) result shows that managers of Malaysian firms consider past year dividend in dividend payout decision. Baker and Smith (2006) support the Pandey (2001) results.

Current year earning negatively affect dividend payout ratio of the selected firms. Our Co relation matrix and OLS result shows that this negative relationship of change in current year earnings with dividend payout ratio is significant. Firms with growing income have more investment opportunity for which they need more finance. Due to this reason they retained major portion of profit for reinvestment in profitable projects. Ahmed and Javid (2008) concluded that investment opportunity has negative relationship with dividend payout ratio in case of Pakistani listed firms. Ahmed and Attiya (2009) claimed that relationship between growth opportunity and dividend payout is insignificant. Similar result found by Rafique (2012) of Pakistani listed firms. Ahmed and Javid (2008) find out that dividend policy is more sensitive to current year earnings as compare to past year dividend. Ahmed and Attyia (2009) study suggests that Pakistani firms dividend policy relay on current year earnings and past year dividend. Asif et al. (2001) claims that change in current year earning has no effect on dividend policy of Pakistani listed firms. Asif et al. (2010) also found insignificant relationship of change in earnings with dividend payout ratio of Pakistani listed firms. Rafique (2012) also concluded that earnings are irrelevant with dividend payout ratio in case of Pakistani listed firms.

Variable change in sales negatively affect dividend payout ratio of the selected firms. But statistically this relationship is insignificant. Amidu and Abore (2006) results shows significant and negative relationship of sales growth with dividend payout ratio. They stated that firms can predict their future from sales growth. Growing firms needs more capital to finance their growth. Thus growing firms retained major portion of the earnings and pay low divined. Jeong (2008) confirms the results of Amidu and Abore (2006). He explained that in case of Korea Stock Exchange listed firms sales growth is probable to be negatively associated to the degree of dividend smoothing in term of dividend payout. He imply signaling theory that firms having growth opportunity or growth in sales are likely to pay high dividend to communicate information with market. At the other hand, growing firms has need funds for financing their valuable investment opportunity thus they pay low dividend and retain major portion of earnings.

\subsection{Theoretical and practical implication of the study}

The findings of the study contributed to the current literature on dividend policy by providing evidence from the perspective of Pakistani public listed firms. Dividend policy is an important decision that each firm has to make. This study provides some useful information about the dividend policy of firms in Pakistani firms listed on Karachi Stock Exchange. In a nutshell, it can be stated that the findings of the study highlight that how changes in stock prices effect dividend policy of Pakistani firms. Thus the findings of this study are helpful for managers, policy maker and investors. The implications for 
stock holders from this study are that, increase or decrease in stock prices has negatively insignificant effect on dividend payout ratio in Pakistan and previous year divined positively affect dividend payout ratio so they can expect dividend from the firms which have dividend paying history. Current year earnings has negatively affect dividend payout ratio which means that growing firms has more funds for investment, thus shareholder expect low dividend from growing firms. Whereas managers in Pakistan need to retain major portion of the profit due to need of fuds for investing in profitable projects.

\subsection{Future Research}

On the basis of findings of this study, for future study the following recommendations can be made:

- In this study, only forty-two Pakistani firms are studied, it is recommended to extend the number of sample firms in future study.

- Four variables namely change in stock prices, changes in earnings, changes in sales and previous year dividend are used to determine dividend policy, it is recommended to extend the number of explanatory variables in future study.

- In this study only Pakistani capital market is studied, it may be suggested to test the hypothesis of this study in some other research settings.

\section{Reference}

Adaoglu, C. (2000). Instability in the dividend policy of the Istanbul Stock Exchange (ISE) Corporations: Evidence from an Emerging market. Emerging Markets Review, 1(3), 252-270.

Aharony, J. \& Swary, I. (1980). Quarterly dividend and earnings announcements and stockholders' returns: An empirical analysis. The Journal of Finance, 35(1), 1-12.

Ahmed, H. \& Javid, A. Y. (2008). Dynamics and determinants of dividend policy in Pakistan: Evidence from Karachi Stock Exchange Non-Financial listed Firms.

Allen, F. \& Michaely, R. (2003). Payout policy. Handbook of the Economics of Finance, 1,337- 429.

Asquith, P., \& Mullins Jr, D. W. (1986). Signalling with dividends, stock repurchases, and equity issues. Financial Management, 27-44.

Baker, H. K. \& Powell, G. E. (1999). How corporate managers view dividend policy. Quarterly Journal of Business and Economics, 17-35.

Baker, H. K., Farrelly, G. E. \& Edelman, R. B. (1985). A survey of management views on dividend policy. Financial management, 78-84.

Baker, M. \& Wurgler, J. (2004). Appearing and disappearing dividends: The link to catering incentives. Journal of Financial Economics, 73(2), 271-288.

Barnea, A., Haugen, R. A. \&Senbet, L. W. (1981). Market imperfections, agency problems, and capital structure: a review. Financial management, 7-22.

Ben Naceur, S., Goaied, M. \& Belanes, A. (2005). A re-examination of dividend policy: A dynamic panel data analysis. Available at SSRN 856384.

Black, F. (1976). The dividend puzzle. The Journal of Portfolio Management,2(2), 5-8. 
Brennan, M. J. (1970). Taxes, Market Valuation and Corporate Financial Policy. National Tax Journal, 23(4), 417-427.

Brigham, E. F., \& Gordon, M. J. (1968). Leverage, dividend policy, and the cost of capital. The Journal of finance, 23(1), 85-103.

Chay, J. B., \& Suh, J. (2009). Payout policy and cash-flow uncertainty. Journal of Financial Economics, 93(1), 88-107.Business and Economics, 17-35.

Collins, S. M., Bosworth, B. P., \& Rodrik, D. (1996). Economic growth in East Asia: Accumulation versus assimilation. Brookings papers on economic activity, (2), 135- 203.

Crutchley, C. E., \& Hansen, R. S. (1989). A Test of the Agency Theory of Managerial Ownership, Corporate Leverage and Corporate Dividends. Financial Management, 36-46.

DeAngelo, H., DeAngelo, L. \& Skinner, D. J. (2004). Are dividends disappearing? Dividend concentration and the consolidation of earnings.Journal of Financial Economics, 72(3), 425-456.

D'Souza, J. \& Saxena, A. K. (1999). Agency Cost, Market Risk, Investment Opportunities and Dividend Policy: An International Perspective. Managerial Finance, 25(6), 35-43.

Easterbrook, F. H. (1984). Two Agency-Cost Explanations of Dividends. The American Economic Review, 74 (4), 650-659.

Eije, V., Henk, J., \& Megginson, W. L. (2006). Dividend Policy in the European Union.

Elton, E. J., \& Gruber, M. J. (1970). Marginal stockholder tax rates and the clientele effect. The Review of Economics and Statistics, 68-74.

Eriotis, N. (2011). The effect of distributed earnings and size of the firm to its dividend Policy: Some Greek data. International Business \& Economics Research Journal (IBER), 4(1).

Fama, E. F. \& French, K. R. (2001). Disappearing dividends: changing firm characteristics or lower propensity to pay? Journal of Financial Economics, 60(1), 3-43.

Fama, E. F. \& Jensen, M. C. (1983). Agency Problems and Residual Claims. The journal of law

Economics, 26(2), 327-349.

Fama, E. F. \& Jensen, M. C. (1983). Separation of Ownership and Control. The Journal of Law \& Economics, 26(2), 301-325.

Farinha, J., \& López-de-Foronda, Ó. (2009). The relation between dividends and insider ownership in different legal systems: international evidence. The European Journal of Finance, 15(2), 169-189.

Gordon, M. J. (1963). Optimal Investment and Financing Policy. The Journal of finance, 18(2), 264-272. 
Green, P., Pogue, M., \& Watson, I. (1993). Dividend policy and its relationship to investment and financing policies: empirical evidence using Irish data. Irish Journal of Management, 14(2), 69.

Haider, J., Ali, A. \&Sadiq, T. (2012). Earning Management and Dividend Policy: Empirical evidence from Pakistani listed companies. European Journal of Business and Management, 4(1), 83-90.

Hashemijoo, M., Mahdavi Ardekani, A. \& Younesi, N. (2012). The impact of Dividend Policy on Share price volatility in the Malaysian stock market. Journal of business studies quarterly, 4(1).

Healy, P. M., \& Palepu, K. G. (1988). Earnings Information Conveyed by Dividend Initiations and Omissions. Journal of Financial Economics, 21(2), 149-175.

Higgins, R. C. (1972). The Corporate Dividend-Saving decision. Journal of Financial and Quantitative Analysis, 7(02), 1527-1541.

Imran, K. (2011). Determinants of dividend payout policy: A case of Pakistan Engineering Sector. The Romanian Economic Journal, 41, 47-60.

Jensen, G. R., Solberg, D. P. \& Zorn, T. S. (1992). Simultaneous Determination of Insider Ownership, Debt, and dividend policies. Journal of financial and Quantitative analysis, 27(02), 247-263.

Jensen, M. C., \&Meckling, W. H. (1976). Theory of the firm: Managerial behavior, agency costs and ownership structure. Journal of financial economics, 3(4), 305360 .

Jeong, J. (2011). An investigation of Dynamic Dividend Behavior in Korea. The International Business \& Economics Research Journal, 10(6), 21.

Kalay, A. \& Loewenstein, U. (1985). Predictable events and excess returns: The case of dividend announcements. Journal of Financial Economics, 14(3), 423-449.

Kent Baker, H., Saadi, S., Dutta, S. \& Gandhi, D. (2007). The perception of dividends by Canadian managers: new survey evidence. International Journal of Managerial Finance, 3(1), 70-91.

Khang, K., \& King, T.-H. D. (2006). Does dividend policy relate to Cross Sectional variation in information asymmetry? Evidence from returns to insider trades. Financial Management, 35(4), 71-94.

Kumar, J. (2006). Ownership structure and dividend payout policy in India. Journal of Emerging Market Finance, 5(1), 15-58.

Lease, R. C., John, K., Kalay, A., Loewenstein, U. \& Sarig, O. H. (1999). Dividend Policy: Its Impact on Firm Value. OUP Catalogue.

Lintner, J. (1956). Distribution of Incomes of Corporations Among Dividends, Retained Earnings, and taxes. American Economic Review, 46(2), 97-113.

Litzenberger, R. H. \& Ramaswamy, K. (1979). The effect of personal taxes and dividends on capital asset prices: Theory and empirical evidence. Journal of financial economics, 7(2), 163-195. 
Litzenberger, R. H., \&Ramaswamy, K. (1982). The Effects of Dividends on Common Stock Prices Tax Effects or Information Effects? The Journal of Finance, 37(2), 429-443.

Lloyd, W. P., Jahera, J. S., \& Page, D. E. (1985). Agency costs and dividend payout ratios. Quarterly Journal of Business and Economics, 19-29.

Mehar, A. (2005). Corporate governance and dividend policy. Pakistan Economic and Social Review (2005): 93-106.

Mehta, A. (2012). An Empirical Analysis of Determinants of Dividend Policy-Evidence from the UAE companies. Global Review of Accounting and Finance, 3(1), 1831.

Miller, M. H., \& Modigliani, F. (1961). Dividend policy, growth, and the valuation of shares. The Journal of Business, 34(4), 411-433.

Miller, M. H., \& Modigliani, F. (1961). Dividend Policy, Growth, and the Valuation of Shares. Journal of Business, 34(4), 411-433.

Miller, M. H., \& Rock, K. (1985). Dividend policy under asymmetric information. The Journal of finance, 40(4), 1031-1051.

Miller, M. H., \& Scholes, M. S. (1978). Dividends and taxes. Journal of Financial Economics, 6(4), 333-364.

Mueller, D. C. (1967). The firm decision process: An econometric investigation. The Quarterly Journal of Economics, 58-87.

Nishat, M., \& Irfan, C. M. (2004). Dividend policy and stock price volatility in Pakistan.In PIDE-19 ${ }^{\text {th }}$ Annual General Meeting and Conference (pp. 13-15).

Nizar Al-Malkawi, H. A. (2007). Determinants of corporate dividend policy in Jordan: An application of the Tobit Model. Journal of Economic and Administrative Sciences, 23(2), 44-70.

Omet, G. S. (2004). Dividend Policy Behaviour in the Jordanian Capital Market. International Journal of Business, 9(3).

Pani, U. (2008). Dividend Policy and Stock Price Behaviourin Indian Corporate Sector: A panel data approach. Indian institute of technology. http://ssrn.com/abstract,1216171.

Partington, G. H. (1984). Dividend Policy and Target Payout Ratios. Accounting \& Finance, 24(2), 63-74.

Poterba, J. M., \& Summers, L. H. (1984). The Persistence of Volatility and Stock Market Fluctuations.

Pruitt, S. W. \& Gitman, L. J. (1991). The interactions between the investment, financing and dividend decisions of major US firms. Financial review, 26(3), 409430.

Rafique, M. (2012). Factors affecting dividend payout: Evidence from listed nonfinancial firms of Karachi Stock Exchange. Business Management Dynamics, 1(11), 76-92. 
Rozeff, M. S. (1982). Growth, beta and agency costs as determinants of dividend payout ratios. Journal of financial Research, 5(3), 249-259.

Rozeff, M. S. (1982). Growth, Beta and Agency Costs as Determinants of Dividend Payout Ratios. Journal of financial Research, 5(3), 249-259.

Shleifer, A. \&Vishny, R. W. (1997). A survey of corporate governance. The journal of finance, 52(2), 737-783.

Yuan, H., \& Zafar, N. (2010). Earnings management and dividend policy an empirical comparison between Pakistani listed companies and Chinese listed companies. International Research Journal of Finance and Economics, (35). 
